\title{
PENGARUH KUALITAS AUDIT TERHADAP MANAJEMEN LABA APADA PERUSAHAAN PERBANKAN YANG TERDAFTAR DI BURSA EFEK INDONESIA
}

\author{
Mutia Ola Tresia Tarigan ${ }^{1}$, Afni Eliana Saragih ${ }^{2}$ \\ ${ }^{1,2}$ Fakultas Ekonomi Program Studi Akuntansi Universitas Katolik Santo Thomas \\ mutiaola23@gmail.com ${ }^{1}$ \\ afni.elianasaragih@gmail.com ${ }^{2}$
}

\begin{abstract}
ABSTRAK
Penelitian ini dilakukan untuk menguji pengaruh Kualitas Audit yang diproksikan dengan Ukuran KAP, Auditor Spesialis Industri dan Opini auditor terhadap Manajemen Laba pada perusahaan Perbankan yang terdaftar di Bursa Efek Indonesia periode 2017-2018. Populasi dalam penelitian ini sejumlah 45 perusahaan Perbankan yang sudah dan masih terdaftar di Bursa Efek Indonesia periode 2017-2018. Teknik pengambilan sampel yang digunakan adalah purposive sampling dan diperoleh sampel sebanyak 43 perusahaan. Teknik analisis data yang digunakan adalah dengan menggunakan uji regresi linier berganda. Hasil penelitian menunjukkan Ukuran KAP berpengaruh positif signifikan terhadap Manajemen Laba, Auditor Spesialis Industri tidak berpengaruh signifikan terhadap Manajemen Laba dan Opini Auditor tidak berpengaruh signifikan terhadap manajemen laba. Secara simultan Ukuran KAP, Auditor Spesialis Industri dan Opini Auditor berpengaruh signifikan terhadap manajemen Laba.
\end{abstract}

Kata kunci : Manajemen Laba, Kualitas Audit, Ukuran KAP, Auditor Spesialis Industri, Opini Auditor

\section{PENDAHULUAN}

Laporan keuangan merupakan sumber informasi mengenai posisi keuangan perusahaan, kinerja perusahaan, maupun perubahan posisi keuangan perusahaan. Laporan keuangan berfungsi sebagai wujud pertanggungjawaban perusahaan terhadap pihak yang berkepentingan, baik internal maupun eksternal dan juga membantu dalam pengambilan keputusan-keputusan ekonomi. Untuk menghasilkan laporan keuangan yang berkualitas, dibutuhkan peran auditor di dalamnya. Auditor adalah seseorang yang memiliki kualifikasi tertentu dalam melakukan audit atas laporan keuangan dan kegiatan perusahaan. Dalam menjalankan tugasnya, auditor berpedomaan pada Standar Profesional Akuntan Publik (SPAP) dan Standar Akuntansi Keuangan (SAK) yang diterbitkan oleh Ikatan Akuntan Indonesia (IAI) diharapkan dapat berperan meningkatkan kualitas informasi yang disajikan. 
Namun demikian, praktik manajemen laba pernah terjadi. Salah satu kasus yang diingat publik adalah skandal Perusahaan Enron Corp, Perusahaan terbesar ke tujuh di AS yang bergerak di bidang industri energi para manajernya memanipulasi angka yang menjadi dasar untuk memperoleh kompensasi moneter yang besar (Boediono 2005 dalam Indriani 2010). Praktik kecurangan yang dilakukan antara lain yaitu di Divisi Pelayanan Energi, para eksekutif melebih-lebihkan nilai kontrak yang dihasilkan dari estimasi internal. Pada proyek perdagangan luar negerinya misal di India dan Brasil, para eksekutif membukukan laba yang mencurigakan. Strategi yang salah, investasi yang buruk dan pengendalian keuangan yang lemah menimbulkan ketimpangan neraca yang sangat besar dan harga saham yang dilebih-lebihkan. Akibatnya ribuan orang kehilangan pekerjaan dan kerugian pasar milyaran dollar pada nilai pasar.

Kejadian kegagalan audit di beberapa perusahaan semakin menurunkan kepercayaan masyarakat dunia terhadap profesi akuntan khususnya auditor. Masyarakat dan pihak-pihak yang berkepentingan dengan laporan keuangan meragukan kredibilitas dan integritas auditor dalam meminimalkan praktek manajemen laba yang terjadi di perusahaan (Sulistiyanto 2008). Alasan tersebut yang menjadikan pengaruh kualitas audit terhadap besarnya manajemen laba oleh manajer perusahaan sebagai fokus dari penelitian ini.

Earnings Management (manajemen laba) dapat digambarkan sebagai suatu kondisi dimana manajemen melakukan intervensi dalam proses penyusunan laporan keuangan bagi pihak eksternal sehingga dapat meratakan, menaikkan, dan menurunkan laba (Schipper 1989 dalam Ningsaptiti 2010). Dalam penelitian Ini jika hasil perhitungan manajemen laba positif maka terjadi manajemen laba pada perusahaan. Manajemen laba timbul karena adanya kesenjangan informasi yang dimiliki manajemen dengan pihak eksternal. Manajemen dianggap lebih banyak memiliki informasi mengenai perusahaan dibandingkan dengan pihak eksternal. Kesenjangan informasi yang dimilki manajemen dengan pihak eksternal dikenal dengan asimetri informasi (information asymmetry). Kesenjangan informasi ini dimanfaatkan oleh pihak manajemen untuk bertindak sesuai dengan kepentingannya. Kualitas audit dapat diproksikan dengan: Ukuran KAP, Auditor Spesialis Industri, Opini Auditor.

Auditing yang berkualitas tinggi (high-quality auditing) bertindak sebagai pencegah manajemen laba yang efektif, karena reputasi manajemen akan hancur dan nilai perusahaan akan turun apabila pelaporan yang salah ini terdeteksi dan terungkap (Ardiati 2005 dalam Indriani 
2010). Ratmono (2010) dalam Rahmadika (2011) berpendapat bahwa KAP Big Four adalah auditor yang memiliki keahlian dan reputasi tinggi dibandingkan dengan KAP Non Big Four. Sehingga mampu mendeteksi tindakan manajemen laba yang dilakukan klien, sehingga manajer akan cenderung melakukan pembatasan terhadap besarnya akrual diskresioner.

Krishnan (2003) dalam Amijaya (2013) Auditor spesialis industri memberikan jasa lebih dan kredibel, yang artinya auditor akan mampu untuk mendukung audit yang lebih efektif dalam kemampuan untuk mendeteksi dan mengatasi manajemen laba dibandingkan yang bukan Auditor Spesialis Industri. Spesialisasi industri KAP merupakan dimensi dari kualitas audit, sebab pengetahuan dan pengalaman auditor tentang industri merupakan salah satu elemen dari keahlian auditor.

Menurut Arens (2006:20) Opini audit adalah pernyataan standard dari kesimpulan auditor yang didapatkan berdasarkan kesimpulan dari proses audit. Proses audit yang independen biasanya diakhiri dengan pernyataan mengenai kewajaran dan keterandalan laporan keuangan tersebut. Perusahaan yang memperoleh opini wajar tanpa pengecualian akan cenderung lebih cepat pelaporannya dibandingkan perusahaan yang memperoleh opini selain wajar tanpa pengecualian. Menurut Sukrisno (2017:74) pada akhir pemeriksaannya, auditor memberikan suatu laporan yang terdiri dari lembaran opini dan laporan keuangan. Lembaran opini merupakan tanggungjawab akuntan publik, dimana akuntan publik memberikan pendapatnya atas kewajaran laporan keuangan yang disusun oleh manajemen.

Semakin baik opini yang diterima oleh perusahaan menandakan bahwa semakin baik pula kualitas laba perusahaan tersebut yang menandakan semakin kecil kemungkinan terjadinya manajemen laba. Opini audit berguna sebagai sumber informasi yang dipakai sebagai alat pengukuran kualitas dan wajar tidaknya laporan keuangan suatu perusahaan. Dikeluarkannya opini suatu laporan keuangan oleh auditor maka diharapkan dapat mencerminkan kualitas laporan keuangan perusahaan tersebut.

Penelitian tentang manajemen laba telah banyak dilakukan, namun memiliki hasil yang berbeda-beda diantaranya adalah sebagai berikut: Penelitian Rachmawati (2013) tentang Pengaruh Kualitas Auditor Terhadap Manajemen Laba (Studi Empiris pada Perusahaan Non Keuangan yang Terdaftar di Bursa Efek Indonesia Tahun 2009-2011). Penelitian tersebut bertujuan untuk menguji pengaruh kualitas auditor terhadap manajemen laba. Hasil penelitian menunjukkan bahwa Auditor 
spesialis industri dan auditor Big Four secara bersama tidak memiliki pengaruh terhadap manajemen laba.

Penelitian Sugiarti (2016) tentang Pengaruh Kualitas Audit terhadap Manajemen Laba (Studi pada Perusahaan Perbankan di Bursa Efek Indonesia tahun 2012-2014). Penelitian ini bertujuan untuk mengetahui pengaruh kualitas audit terhadap manajemen laba. Hasil penelitian Ukuran KAP berpengaruh positif terhadap manajemen laba, Auditor spesialis industri tidak berpengaruh terhadap manajemen laba. Penelitian Amijaya (2013) tentang Pengaruh Kualitas Audit Terhadap Manajemen Laba Studi Empiris pada Perusahaan Perbankan yang Terdaftar di BEI Tahun 2008-2011. Penelitian ini bertujuan untuk mengetahui pengaruh kualitas audit terhadap manajemen laba. Hasil penelitian ukuran KAP, auditor spesialis industri memberikan pengaruh terhadap manajemen laba dengan arah koefisien negatif.

Penelitian ini bertujuan untuk menguji pengaruh kualitas audit terhadap manajemen laba pada perusahaan perbankan yang terdaftar di bursa efek indonesia. Adapun perbedaan penelitian ini terletak pada variabel Independen dalam penelitian ini peneliti menambah variabel independen yaitu opini auditor. Selanjutnya periode penelitian ini tahun 2017-2018.

\section{TINJAUAN PUSTAKA DAN PENGEMBANGAN HIPOTESIS}

\section{Tinjauan Pustaka}

\section{a. Manajemen Laba}

Menurut sulistyanto (2008) manajemen laba adalah upaya manajer perusahaan untuk mengintervensi atau mempengaruhi informasi-informasi dalam laporan keuangan dengan tujuan untuk mengelabui stakeholder yang ingin mengetahui kinerja dan kondisi perusahaan. Seringkali proses ini mencakup laporan keuangan,terutana angka yang paling bawah adalah laba. Manajemn laba dapat berupa kosmetik, jika manajer memanipulasi akrual yang tidak memiliki konsekuensi arus kas. Manajemen laba juga terlihat nyata jika manejer memilih tindakan dengan konsekuensi arus kas dengan tujuan mengubah laba. manajemen kosmetik laba merupakan hasil dari kebebasan dalam aplikasi akuntansi akrual yang mungkin terjadi.

Berdasarkan beberpa defenisi diatas maka disimpulkan bahwa manajemen laba merupakan suatu tindakan oleh manejer dengan cara penggolahan data atau informasi akuntansi agar jumlah laba yang tercatat dalam laporan keuangan sampai dengan keinginan manajer, baik untuk kepentingan pribadi maupun kepentingan perusahaan. 
Perilaku manajemen laba dapat dijelaskan di dalam positive accounting theory (PAT) dan teori keagenan (agency theory). Menurut scott (2009) mendefinisikan positive accounting theory (PAT) sebagai adalah memprediksi tindakan seperti pilihan kebijakan akuntansi oleh manajer perusahaan dan bagaimana manajer akan menanggapi usulan standar akuntansi baru. Terdapat tiga hipotesis dalam positive accounting theory (PAT) yang dapat dijadikan sebagai dasar pemahaman motivasi tindakan manajemen laba yaitu:

\section{The Bonus Plan Hypothesis}

Hipotesis ini menyatakan bahwa manajer perusahaan dengan rencana bonus lebih mungkin untuk memilih prosedur akuntansi yang menggeser laba yang dilaporkan dari periode mendatang ke periode berjalan.

\section{The Debt Covenant Hypothesis}

Hipotesis ini menyatakan bahwa semua hal yang lain tetap sama dan semakain dekat perusahaan dengan pelanggaran perjanjian hutang dan semakin besar probabilitas pelanggaran perjanjian hutang tersebut, maka semakin mungkin manajer menggunakan metode akuntansi yang akan meningkatan laba yang dilaporkan pada periode mendatang ke periode sekarang.

\section{The Political Cost Hypothesis}

Hipotesis ini menyatakan jika pada perusahaan yang besar memiliki biaya politik tinggi, maka manajer akan lebih memilih metode akuntansi yang dapat menurunkan laba yang dilaporkan dari periode sekarang ke periode mendatang. Hal ini dilakukan dengan tujuan untuk menghindari regulasi atau keputusan pemerintah, misalnya menaikkan pajak panghasilan perusahaan. Angka-angka yang dilaporkan memiliki kekuatan yang serupa untuk membangun opini dilingkungan perusahaan. Oleh karena laba bersih yang di laporkan merupakan angka yang memperoleh perhatian peling banyak, maka angka ini pula lah yang paling mungkin di manipulasi oleh para manajer.

Manajemen laba biasanya melibatkan serangkaian langkah yang semakin agresif. Menurut scott (2009) langkah tersebut meliputi:

1. Pengaitan secara strategis.

Perusahaan dengan keahliannya dalam penentuan waktu transaksi sehingga keuntungan atau kerugian dalam jumlah besar terjadi dalam kuartal yang sama, sehingga memunculkan tran naik yang mulus pada laba yang dilaporkan. Dengan menggunakan kesadaran atas manfaat yang didapat dari pencapaian target laba yang konsisten atau pelaporan angka 
laba yan stabil, sebuah perusahaan dapat melakukan usaha-usaha tambahan untuk memastikan bahwa beberapa transaksi penting telah diselesaikan dengan cepat atau ditunda sehingga dapat diakui pada kuartal yang paling menguntungkan.

2. Perubahan pada metode atau estimasi dengan pengungkapan penuh.

Perusahaan sering mengganti estimasi akuntansinya yang berhubungan dengan piutang tak tertagih, return atau dana pensiun, umur ekonomis aset, dan lain-lain. Meskipun perubahan ini merupakan suatu bagian yang rutin dari penyesuaian-penyesuaian estimasi akuntansi untuk menampilkan informasi terkini dan tersedia, hal ini dapat digunakan untuk mengatur laba yang dilaporkan. Oleh karena dampak dari perubahan ini di ungkap secara menyeluruh dalam laporan keuangan, maka setiap motivasi manajemen laba dapat dengan mudah dideteksi oleh para pengguna laporan keuangan.

3. Perubahan dalam metode atau estimasi dengan pengungkapan yang minimal atau tanpa pengungkapan sama sekali.

Perubahan tingkat suku bunga yang digunakan untuk memcatat penjualan sewa guna usaha tanpa memberikan gambaran perubahan ini dalam catatan atas laporan keuangan perusahaan. Seeorang mungkin dapat berdebat mengenai betapa lebih sesuainya tingkat bunga yang baru, tetapi yang pasti adalah kelainan untuk mengungkapkan dampak dari perubahan ini dapat menyesatkan para pengguna laporan keuangan. Akibatnya, para pengguna laporan keuangan melakukan evaluasi atas laba yang dilaporkan dengan menggunakan asumsi yang tidak benar, yakni bahwa hasil operasi perusahaan yang dilaporkan dalam laporan keuangan benar-benar berasal dari metode atau estimasi akuntansi yang sama dan yang konsisten dengan tahun sebelumnya, sehingga dapat dibandingkan dengan hasil sebelumnya.

4. Akuntansi Non GAAP (general accepted principle of acounting)

Pada sisi kanan rangkaian manajemen laba terdapat suatu alat manajemen laba yang secara sopan dapat disebut dengan akuntansi non GAAP. Nama yang lebih deskriptif dalam banyak kasus adalah: "pelaporan yang curang" meskipun akuntansi non GAAP sebenarnya dapat juga terjadi akibat kesalahan yang tidak disengaja kekurang hati-hatian.

\section{Transaksi fiktif}

Transaksi fiktif adalah transaksi jual beli efek yang pada bursa yang disengaja dengan tujuan untuk mempengaruhi daya jual dan beli para investor. Para manejer secara sembunyi-sembunyi menyewa gudang yang digunakan untuk menyimpan barang-barang yang diretur untuk 
menghindari pencatatan return penjualan. Hal ini merupakan salah satu contoh kecurangan, yang merupakan suatu pengingkaran atas transaksi.

\section{b. Kualitas Audit}

Pemegang saham membutuhkan informasi yang nantinya akan dijadikan pertimbangan dalam pengambilan keputusan. Informasi tersebut didapat dari laporan keuangan yang telah diaudit oleh auditor. Auditor diharapkan mampu meminimalisasi terjadinya manajemen laba dan segala kecurangan yang dilakukannya demi membuat kesan bahwa laporan keuangan yang telah dibuat terlihat baik. Untuk melakukan itu semua dibutuhkan seorang auditor yang berkualitas yang mampu mendeteksi manajemen laba. Watts dan Zimmerman (1986) dan De Angelo (1981) dalam Amijaya (2013) menyatakan bahwa kualitas auditor tergantung pada relevansi laporan auditor dalam memeriksa hubungan kontraktual dan dalam melaporkan pelanggaran. Menurut Bartov et al dalam Rusmin (2010) menyatakan bahwa auditor yang berkualitas lebih menyukai untuk melaporkan kesalahan dan penyimpangan, serta tidak bersedia untuk menerima praktik akuntansi yang dipertanyakan.

Kualitas audit sendiri sangat berhubungan erat dengan kualitas penyajian pelaporan laporan keuangan. Laporan keuangan yang disajikan auditor berisi informasi-informasi penting bagi pengguna laporan keuangan sehingga laporan keuangan bisa dijadikan sebagai alat pengambil keputusan bagi manajemen perusahaan. Jika informasi dalam laporan keuangan dimanipulasi oleh manajemen, maka kondisi laporan keuangan menjadi tidak valid.

Manipulasi data terkait dengan manajemen laba dapat dilakukan dengan menaikkan atau menurunkan laba perusahaan, sehingga menjadikan proses pengambilan keputusan menjadi tidak valid karena informasi yang disampaikan salah. Manajemen melakukan praktik manipulasi laba karena manajemen laba berkaitan erat dengan prestasi manajemen. Prestasi manajemen menunjukkan seberapa besar kinerja yang diraih perusahaan. Kualitas audit dapat diukur dengan proksi ukuran KAP, Auditor Spesialis Industri dan Opini Auditor.

\section{c. Ukuran KAP}

Kantor Akuntan Publik adalah suatu bentuk organisasi akuntan publik yang memperoleh izin sesuai dengan peraturan perundangundangan yang berusaha dibidang pemberian jasa profesional dalam praktik akuntansi publik. Oleh karena itu perusahaan menggunakan jasa kantor akuntan publik dalam melaksanakan pekerjaan audit terhadap laporan keuangan perusahaan. KAP yang mempunyai tenaga spesialis yang 
menyerahkan satu atau lebih jenis laporan setiap tahunnya Mulyadi (2002).

Hal tersebut terjadi karena adanya anggapan bahwa KAP yang besar memiliki sumber daya, jumlah karyawan dan tingkat kehati-hatian yang lebih tinggi dibandingkan KAP yang kecil. Selain itu KAP yang besar juga memiliki klien-klien besar atau perusahaan-perusahaan yang sudah go public jadi KAP besar cenderung untuk mempertahankan reputasinya.

Ukuran KAP dapat dibedakan menjadi KAP Big Four dan KAP Non Big Four. Auditor Big Four adalah auditor yang memiliki keahlian dan reputasi tinggi dibandingkan dengan auditor Non Big Four. Sehingga auditor berkualitas dan bereputasi tinggi memungkinkan membatasi praktik manajemen laba. Dalam penelitian sebelumnya berpendapat KAP Big Four memberikan kualitas audit yang lebih baik daripada KAP Non Big Four. Adapun KAP yang termasuk dalam kelompok KAP Big Four adalah :

1. Deloitte Touche Tohmatsu (Deloitte) yang berafiliasi dengan Hans Tuanakotta Mustofa \& Halim; Osman Ramli Satrio \& Rekan; Osman Bung Satrio \& Rekan.

2. Ernst \& Young (EY) yang berafiliasi dengan Mutiaio, Sarwoko \& Sandjaja; Purwantono, Sarwoko \& Sandjaja.

3. Klynveld Peat Marwick Goerdeler (KPMG) yang berafiliasi dengan Siddharta Siddharta \& Widjaja.

4. PricewaterhouseCooper (PwC) yang berafiliasi dengan Haryanto Sahari \& Rekan; Tanudiredja, Wibisena \& Rekan.

Kepemilikan KAP yang kompeten kemungkinan dapat membantu waktu penyelesaian audit menjadi lebih segera atau tepat waktu. Penyelesaian waktu audit secara tepat waktu cenderung dapat meningkatkan reputasi KAP dan menjaga kepercayaan klien untuk memakai jasanya kembali untuk waktu yang akan datang. Dengan demikian besar kecilnya KAP cenderung dapat mempengaruhi ketepatan waktu penyampaian laporan keuangan.

\section{d. Auditor Spesialis Industri}

Auditor spesialis industri memberikan jasa lebih dan kredibel, yang artinya auditor akan mampu untuk mendukung audit yang lebih efektif dalam kemampuan untuk mendeteksi dan mengatasi manajemen laba. Spesialis industri KAP merupakan dimensi dari kualitas audit, sebab pengetahuan dan pengalaman auditor tentang industri merupakan salah satu elemen dari keahlian auditor. 
Auditor spesialis industri diharapkan memiliki kinerja yang lebih baik dibandingkan auditor lainnya dalam meminimalisir praktek manajemen laba (Solomon et al 1999 dan Owhoso et al 2002) dalam Amijaya (2013). Auditor spesialis industri ini memiliki kemampuan dan pengalaman yang lebih di suatu bidang industri tertentu. Dengan kemampuan yang dimilikinya, diharapkan auditor dapat menemukan kesalahan saji dengan benar dan dapat meminimalisir praktek manajemen laba. Hal ini berarti bahwa auditor spesialis industri memiliki kemampuan untuk mendeteksi error dan memiliki pengalaman yang lebih baik daripada non auditor spesialis industri.

\section{e. Opini Auditor}

Menurut Arens (2006:20) Opini audit adalah pernyataan standard dari kesimpulan auditor yang didapatkan berdasarkan kesimpulan dari proses audit. Proses audit yang independen biasanya diakhiri dengan pernyataan mengenai kewajaran dan keterandalan laporan keuangan tersebut. Perusahaan yang memperoleh opini wajar tanpa pengecualian akan cenderung lebih cepat pelaporannya dibandingkan perusahaan yang memperoleh opini selain wajar tanpa pengecualian. Lembaran opini merupakan tanggungjawab akuntan publik, dimana akuntan publik memberikan pendapatnya atas kewajaran laporan keuangan yang disusun oleh manajemen. Menurut Mulyadi (2002:18-20) ada lima jenis opini auditor, sebagai berikut:

1. Pendapat wajar tanpa pengecualian (unqualified opinion report)

2. Pendapat wajar tanpa pengecualian dengan tambahan penjelasan (qualified opinion report with explanatory language)

3. Pendapat wajar dengan pengecualian (qualified opinion)

4. Pendapatan tidak wajar (adverse opinion)

5. Pernyataan tidak memberikan pendapat (disclaimer of opinion)

Auditor akan mengeluarkan salah satu dari kelima opini tersebut setelah melakukan pemeriksaan laporan keuangan perusahaan yang diaudit sesuai dengan standar dan prosedur audit yang berlaku. Perusahaan biasanya mengharapkan auditor mengeluarkan opini wajar tanpa pengecualian (unqualified opinion). Dengan mendapatkan unqualified opinion menandakan bahwa laporan keuangan perusahaan telah disajikan secara wajaran sesuai dengan standar-standar akuntansi yang berlaku. Semakin bagus opini yang diterima oleh perusahaan menandakan bahwa semakin bagus pula kualitas laba perusahaan tersebut yang menandakan semakin kecil kemungkinan terjadinya manajemen laba. Opini audit berguna sebagai sumber informasi yang dipakai sebagai alat pengukuran 
kualitas dan wajar tidaknya laporan keuangan suatu perusahaan. Dikeluarkannya opini suatu laporan keuangan oleh auditor maka diharapkan dapat mencerminkan kualitas laporan keuangan perusahaan.

\section{Pengembangan Hipotesis}

a. Pengaruh Ukuran KAP terhadap Manajemen Laba

Timbulnya praktik manajemen laba dapat dijelaskan dengan teori agensi. Di dalam teori agensi mengasumsikan bahwa agen memiliki lebih banyak informasi daripada prinsipal, karena principal tidak dapat mengamati kegiatan yang dilakukan agen secara terus-menerus. Dalam kondisi asimetri seperti ini perlu ada orang ketiga yaitu auditor sebagai pihak yang dianggap mampu menjembatani kepentingan pihak prinsipal (shareholder) dan pihak manajer (agent) dalam mengelola keuangan perusahaan. pernyataan De Angelo (1981) dalam Christian (2014) yang berpendapat bahwa auditor yang berasal dari Big Four memberikan kualitas yang lebih baik dibandingkan auditor Non-Big Four. Penggunaan auditor berkualitas tinggi dapat mencegah emiten berlaku curang dalam menyajikan suatu laporan keuangan yang tidak relevan ke masyarakat.

KAP Big Four memiliki keahlian dan reputasi yang tinggi dibandingkan dengan KAP Non-Big Four. Keahlian yang dimiliki KAP Big Four yaitu dengan pendidikan, pelatihan dan pengalaman yang dimiliki menjadikan orang yang ahli dalam bidang akuntansi dan auditing serta memiliki kemampuan untuk menilai secara objektif sesuai dengan prinsip akuntansi yang berterima umum dalam melakukan audit dengan memberikan pendapatnya atas laporan keuangan sehingga laporan keuangan dapat dipertanggungjawabkan sehingga bisa mendeteksi kesalahan penyajian posisi keuangan yang dilakukan manajer. Berdasarkan dari keahlian yang dimiliki KAP Big Four, maka KAP Big Four lebih tinggi dalam menghambat praktik manajemen laba dibandingkan KAP Non-Big Four lebih rendah dalam menghambat praktik manajemen laba. Dalam penelitian yang dilakukan Sugiarti (2016) yang menunjukkan perusahaan yang memiliki kualitas auditor yang tinggi dapat menggurangi terjadinya discretionary accruals dibandingkan dengan yang diaudit oleh auditor yang berkualitas rendah. Berdasarkan hasil penelitian di atas dapat dinyatakan bahwa semakin baik kualitas audit akan mengurangi kecenderungan manajer melakukan manajemen laba. Dengan demikian hipotesis yang dapat dirumuskan adalah sebagai berikut :

H1 : Ukuran KAP berpengaruh positif terhadap manajemen laba. 


\section{b. Pengaruh Audit Spesialis Industri Terhadap Manajemen Laba}

Teori agensi mengasumsikan bahwa manusia itu selalu self interest maka diperlukan pihak ketiga yang independen yang menjadi mediator antara pemegang saham dan agen, dalam hal ini auditor (Ningsaptiti 2010). Untuk mengatasi agency problem maka dalam hubungan keagenan diperlukan auditor yang berkredibilitas yang benar-benar mengetahui kondisi perusahaan yaitu auditor spesialis industri. Oleh sebab itu, auditor spesialis industri mempunyai peran sebagai pemonitoring laporan keuangan karena pemegang saham lebih percaya pada informasi pada laporan keuangan dengan kualitas audit yang tinggi (Ningsaptiti 2010).

Zhou dan Elder (2004) dalam Rahmadika (2011) menyatakan bahwa spesialisasi industri KAP merupakan dimensi dari kualitas audit, sebab pengetahuan dan pengalaman auditor tentang industri merupakan salah satu elemen dari keahlian auditor. Auditor spesialis industri mampu menghasilkan audit yang berkualitas berdasarkan dari pengalaman mereka dalam melayani klien. Dengan pengetahuan yang dimiliki oleh auditor spesialis industri membuat auditor tersebut memahami kondisi perusahaan kliennya sehingga dapat meminimalkan praktik penyimpangan laporan keuangan yang dilakukan manajemen. Hal ini sejalan dengan pendapat yang dikemukakan PricewaterhouseCooper (2002) menyatakan bahwa kualitas audit tergantung pada berbagai faktor termasuk pengetahuan auditor dan pemahaman tentang perusahaan yang diaudit dimana dia beroperasi.

Ningsaptiti (2010) menyatakan bahwa KAP yang memiliki banyak klien dalam industri yang sama, akan memiliki pemahaman yang lebih dalam tentang risiko audit khusus yang mewakili industri tersebut. Auditor spesialis industri memiliki informasi yang banyak, sehingga mempunyai kemampuan memeriksa laporan keuangan lebih terinci karena auditor spesialis tersebut mengetahui kondisi perusahaan dan sektor perusahaan yang diaudit terfokus hanya pada spesialis industrinya. Berbeda dengan non auditor spesialis industri yang kurang memiliki banyak informasi dan auditornya mengaudit tidak terfokus pada spesialis industrinya. Sehingga perusahaan yang diaudit oleh auditor spesialis industri lebih besar dalam mendeteksi manajemen laba yang dilakukan manajer dibandingkan dengan auditor yang bukan auditor spesialis industri yang lebih rentan tidak terdeteksinya praktik manajemen laba. Dalam penelitan Christian (2014) Hasil penelitian Auditor spesialis industri memiliki pengaruh negatif terhadap manajemen laba. Seharusnya dari penelitaian diatas semakin baik 
spesialisasi industri auditor maka akan semakin mengurangi kecenderungan manajer melakukan manajemen laba. Dengan demikian hipotesis yang dapat dirumuskan adalah sebagai berikut :

$\mathrm{H} 2$ : Auditor spesialis industri berpengaruh negatif terhadap manajemen laba.

\section{c. Pengaruh Opini Auditor terhadap Manajemen Laba}

De Angelo (1981) dalam Christian (2014) menyebutkan bahwa kualitas audit merupakan probabilitas dimana seorang auditor menemukan dan melaporkan tentang adanya suatu pelanggaran dalam sistem akuntansi auditnya. Kantor Akuntan Publik (KAP) yang memiliki kualitas audit yang tinggi memperbesar risiko terungkapnya kecurangan akuntansi sehingga perusahaan cenderung menghindarinya. Peranan auditor dalam menghasilkan laporan audit sangatlah penting dengan memberikan opini atau pendapat atas laporan keuangan suatu perusahaan. Auditing memberikan nilai tambah bagi laporan keuangan perusahaan karena akuntan publik sebagai pihak yang independen pada akhir pemeriksaannya akan memberikan pendapat mengenai kewajaran posisi keuangan, hasil usaha, perubahan ekuitas, dan laporan arus kas.

Jika laporan keuangan sudah diaudit, dan mendapat opini Wajar Tanpa Pengecualian (Unqualified Opinion) dari KAP berarti pengguna laporan keuangan bisa yakin bahwa laporan keuangan bebas dari salah saji material dan disajikan sesuai prinsip akuntansi yang berlaku umum di Indonesia (Sukrisno 2017). Penelitian Amijaya (2013) juga menunjukkan bahwa opini auditor memberikan pengaruh negatif terhadap manajemen laba. Dengan demikian hipotesis yang dapat dirumuskan adalah sebagai berikut :

H3: Opini Auditor berpengaruh negatif terhadap manajemen laba.

\section{METODE PENELITIAN}

\section{Populasi dan Sampel}

Populasi penelitian ini adalah seluruh perusahaan Perbankan yang terdaftar di Bursa Efek Indonesia yang berjumlah 45 perusahaan pada tahun 20172018. Pemilihan sampel ditentukan dengan purposive sampling dengan tujuan untuk mendapatkan sampel representatif sesuai dengan kriteria yang ditentukan. Kriteria yang ditetapkan dalam pemilihan sampel penelitian ini sebagai berikut .Perusahaan Perbankan yang terdaftar di BEI tahun 20172018

1. Perusahaan yang telah menerbitkan laporan keuangan yang telah diaudit untuk periode yang berakhir 31 Desember tahun 2017-2018 
2. Perusahaan perbankan yang listing di BEI selama dua tahun berturut-turut dari tahun 2017-2018

3. Data tersedia lengkap

Proses pemilihan sampel berdasarkan kriteria dapat dilihat pada tabel dibawah ini:

Tabel 1. Proses Pemilihan sampel

\begin{tabular}{|l|l|c|}
\hline No & \multicolumn{1}{|c|}{ Kriteria } & $\begin{array}{c}\text { Jumlah } \\
\text { Perusahaan }\end{array}$ \\
\hline 1 & $\begin{array}{l}\text { Perusahaan perbankan yang terdaftar di BEI tahun } \\
2017-2018\end{array}$ & 45 \\
\hline 2 & $\begin{array}{l}\text { Perusahaan yang tidak menerbitkan laporan keuangan } \\
\text { yang telah diaudit untuk periode yang berakhir 31 } \\
\text { Desember tahun 2017-2018 }\end{array}$ & $(1)$ \\
\hline 3 & $\begin{array}{l}\text { Perusahaan perbankan yang delisting di BEI selama dua } \\
\text { tahun berturut-turut dari tahun 2017-2018 }\end{array}$ & $(1)$ \\
\hline 4 & Data tidak tersedia lengkap & $(0)$ \\
\hline Jumlah Perusahaan Sampel & 43 \\
\hline Tahun Pengamatan & 86 \\
\hline Jumlah Pengamatan Total selama Periode & 8 \\
\hline
\end{tabular}

Sumber : Diolah Oleh Penulis.

Berdasarkan kriteria tersebut, perusahaan yang menjadi sampel penelitian terdiri dari 43 perusahaan, dengan periode 2 tahun sehingga total jumlah data observasi sebanyak 86 sampel. Perusahaan yang menjadi sampel penelitian dapat kita lihat pada tabel berikut:

\section{Operasionalisasi Variabel}

\section{a. Manajemen Laba (Y)}

Manajemen laba yang dihitung dengan discretionary accruals. Besarnya discretionary accruals dihitung menggunakan model DeAngelo (1986) dalam Christian (2014) Model tersebut dapat dituliskan sebagai berikut:

1. Menghitung nilai total dengan persamaan

Dimana:

$$
(T A C)_{t}=\left(N I_{t}-C F F O_{t}\right)
$$

TAC $\mathrm{t}=$ Total Accruals Tahun $\mathrm{t}$

NIt = Laba Bersih Setelah Pajak (net income) Tahun $\mathrm{t}$

CFFOt $=$ Arus Kas dari Aktivitas Operasi (cash flow from operating)

Tahun $\mathrm{t}$ 
2. Perhitungan Nondiscretionary Accruals

DeAngelo (1986) mengasumsikan bahwa total accruals yang nondiscretionary mengikuti pola random walk. Dengan demikian, total accruals yang nondiscretionary (tingkat akrual yang wajar atau normal) pada perioda $t$ diasumsikan sama dengan total accruals yang nondiscretionary pada perioda $\mathrm{t}-1$.

Dimana:

$$
N D A_{t}=T A C_{t-1}
$$

NDA $\mathrm{t}=$ Nondiscretionary Accruals pada Periode $\mathrm{t}$

TAC $\mathrm{t}-1=$ Total Accruals pada Perioda Tahun t -1

3. Menghitung nilai discretionary accruals dengan persamaan :

$$
D A_{t}=\left(T A C_{t}-N D A_{t}\right) / T A_{t}
$$

Dimana :

DAt $=$ Discretionary Accruals pada Periode $\mathrm{t}$

TAt $=$ Total Asset pada Periode $\mathrm{t}$

\section{b. Ukuran KAP (X1)}

Ukuran KAP didefinisikan sebagai ukuran besar atau kecilnya suatu kantor akuntan publik. KAP Big Four dikatakan besar karena KAP tersebut memiliki keahlian dan reputasi yang tinggi dibandingkan dengan KAP Non-Big Four. Adapun KAP yang termasuk Big Four adalah :

1. Deloitte Touche Tohmatsu (Deloitte) yang berafiliasi dengan Hans Tuanakotta Mustofa \& Halim; Osman Ramli Satrio \& Rekan; Osman Bung Satrio \& Rekan.

2. Ernst \& Young (EY) yang berafiliasi dengan Prasetio, Sarwoko \& Sandjaja; Purwantono, Sarwoko \& Sandjaja.

3. Klynveld Peat Marwick Goerdeler (KPMG) yang berafiliasi dengan Siddharta Siddharta \& Widjaja

4. PricewaterhouseCooper $(\mathrm{PwC})$ yang berafiliasi dengan Haryanto Sahari \& Rekan; Tanudiredja, Wibisena \& Rekan.

Ukuran KAP diukur dengan menggunakan variabel dummy. Dimana untuk KAP yang berasal dari Big Four diberikan nilai 1 dan KAP yang bukan berasal dari Big Four diberikan nilai 0 .

\section{c. Auditor Spesialis Industri (X2)}

Jika auditor memiliki pangsa pasar lebih dari 20\% maka auditor tersebut termasuk auditor spesialis industri. Namun, jika auditor memiliki pangsa pasar kurang dari 20\% maka auditor tersebut bukan auditor spesialis industri (Chen et al 2005 dalam Rusmin 2010). Rumus untuk mengukur rasio spesialisasi industri adalah sebagai berikut :

$$
\mathbf{R}=\mathbf{m} / \mathbf{n}
$$


Dimana:

$\mathrm{R}=$ Rasio Spesialisasi Industri

$\mathrm{m}=$ Jumlah Perusahaan Dalam Satu Industri yang Diaudit oleh Auditor yang Sama

$\mathrm{n}=$ Jumlah Perusahaan yang Diaudit oleh Semua Auditor

Pengukuran variabel ini dengan menggunakan variabel dummy sehingga untuk auditor yang spesialis industri diberi nilai 1 dan auditor yang tidak spesialis industri diberi nilai 0 .

\section{d. Opini Auditor (X3)}

Opini auditor dalam penelitian ini diukur dengan melihat jenis opini yang diberikan oleh auditor independen terhadap laporan keuangan. Menurut Mulyadi $(2002 ; 18)$ ada lima opini auditor yang terdiri dari: pendapat wajar tanpa pengecualian (unqualified opinion), pendapat wajar tanpa pengecualian dengan tambahan penjelasan (qualified opinion report with explanatory language), pendapat wajar dengan pengecualian (qualified opinion), pendapat tidak wajar (adverse opinion), dan pernyataan tidak memberikan pendapat (disclaimer opinion). Variabel ini diukur dengan menggunakan dummy untuk perusahaan yang menerima pendapat unqualified opinion diberi kode 1 dan perusahaan yang menerima pendapat selain unqualified opinion diberi kode 0 .

\section{Pengujian Hipotesis}

Model persamaan regresi yang digunakan dapat dirumuskan sebagai berikut (Ghozali, 2018):

$$
\mathrm{Y}=\mathrm{a}+\mathrm{b} 1 \mathrm{X} 1+\mathrm{b} 2 \mathrm{X} 2+\mathrm{b} 3 \mathrm{X} 3+\mathrm{e}
$$

Dimana:

$$
\begin{array}{ll}
\mathrm{Y} & =\text { Manajemen Laba } \\
\mathrm{a} & =\text { Konstanta } \\
\mathrm{b} 1, \mathrm{~b} 2, \mathrm{~b} 3 & =\text { Koefisien regresi variabel UK, SI, OP } \\
\mathrm{X} 1 & =\text { Ukuran KAP } \\
\mathrm{X} 2 & =\text { Auditor Spesialis Industri } \\
\mathrm{X} 3 & =\text { Opini Auditor } \\
\mathrm{e} & =\text { error term }
\end{array}
$$

\section{HASIL PENELITIAN DAN PEMBAHASAAN}

\section{Analisis Statistik Deskriptif}

Berdasarkan data statistik yang diperoleh melalui hasil estimasi dengan program SPSS, maka dilakukan analisis statistik deskriptif untuk 
memberikan gambaran data dalam penelitian ini. Analisis deskriptif dalam penelitian ini dilakukan melalui nilai rata-rata (mean), maksimum, minimum dan standard deviasi dari masing-masing variabel penelitian. Penelitian ini meliputi tiga variabel independen, satu variabel dependen. Variabel independen dalam penelitian ini ialah Kualitas Audit yang terdiri dari Ukuran UKP, Auditor spesialis industri dan Opini auditor. Variabel dependen dalam penelitian ini adalah Manajemen Laba. Data statistik yang diperoleh dalam penelitian ini dapat dilihat pada tabel berikut:

Tabel 2. Hasil Uji Statistik Deskriptif Descriptive Statistics

\begin{tabular}{|l|r|r|r|r|r|}
\hline & \multicolumn{1}{|c|}{$\mathrm{N}$} & \multicolumn{1}{|c|}{ Minimum } & Maximum & \multicolumn{1}{c|}{ Mean } & \multicolumn{1}{c|}{ Std. Deviation } \\
\hline Manajemen Laba & 76 &,- 187 &, 175 &, 00122 &, 079147 \\
Ukuran KAP & 76 & 0 & 1 &, 59 &, 495 \\
Auditor Spes Industri & 76 & 0 & 1 &, 54 &, 502 \\
Opini Auditor & 76 & 0 & 1 &, 97 &, 161 \\
Valid N (listwise) & 76 & & & & \\
\hline
\end{tabular}

Sumber : Hasil Output SPSS v. 22 (data diolah)

Berdasarkan tabel 4.5 menunjukkan bahwa dari jumlah data sebanyak 76 data. Manajemen laba memiliki rata-rata sebesar 0,00122 dengan nilai standar deviasi 0,079147. Ukuran KAP memiliki rata-rata sebesar 0,59 dan nilai standar deviasi 0,495. Auditor spesialis industri memiliki rata-rata sebesar 0,54 dengan nilai standar deviasi 0,502. Opini auditor memiliki rata-rata sebesar 0,97 dengan nilai standar deviasi 0,161.

\section{Hasil Uji Koefisien Determinasi $\left(\mathbf{R}^{2}\right)$}

Analisis determinasi dalam regresi linear berganda digunakan untuk mengetahui persentase sumbangan pengaruh ukuran KAP, Auditor spesialis industri dan Opini auditor secara simultan terhadap Manajemen laba. Koefisien ini menunjukkan seberapa besar persentase variasi variabel independen yang digunakan dalam model mampu menjelaskan variasi variabel dependen.

Tabel 3. Hasil Uji Koefisien Determinasi $\left(\mathbf{R}^{2}\right)$

Model Summary

\begin{tabular}{|l|r|r|r|r|r|}
\hline Model & $\mathrm{R}$ & R Square & $\begin{array}{c}\text { Adjusted R } \\
\text { Square }\end{array}$ & $\begin{array}{c}\text { Std. Error of the } \\
\text { Estimate }\end{array}$ & Durbin-Watson \\
\hline 1 &, $397^{\mathrm{a}}$ &, 158 &, 123 &, 074126 & 2,293 \\
\hline
\end{tabular}

a. Predictors: (Constant), Opini Auditor, Ukuran KAP, Auditor Spes Industri

b. Dependent Variable: Manajemen Laba

Sumber : Hasil Output SPSS v. 22 (data diolah) 
Berdasarkan tabel 4.11 diatas diperoleh nilai koefisien determinasi (Adjusted $R$ Square) sebesar 0,158 atau 15,8\% artinya variabel Independen (ukuran UKP, Auditor spesialis industri dan Opini auditor) secara simultan mempengaruhi variabel dependen yaitu Manajemen laba sebesar 15,8\% sedangkan sisanya 84,2\% ( $1-0,158=0,842)$ dipengaruhi oleh variabel lain yang tidak terungkap atau tidak diteliti dalam penelitian ini.

\section{Pengujian Hipotesis}

Analisis linear berganda digunakan untuk mengetahui pengaruh Ukuran KAP, Auditor spesialis industri dan Opini auditor terhadap Manajemen laba. Analisis ini diolah dengan program SPSS 22. Hasil analisis regresi linear berganda ditunjukkan pada tabel berikut :

\section{Tabel 4. Hasil Analisis Regresi Linear Berganda} Coefficients $^{\mathrm{a}}$

\begin{tabular}{|c|c|c|c|c|c|c|c|}
\hline \multirow[b]{2}{*}{ Model } & \multicolumn{2}{|c|}{$\begin{array}{l}\text { Unstandardized } \\
\text { Coefficients }\end{array}$} & \multirow{2}{*}{$\begin{array}{c}\begin{array}{c}\text { Standardi } \\
\text { zed } \\
\text { Coefficient } \\
\text { s }\end{array} \\
\text { Beta }\end{array}$} & \multirow[b]{2}{*}{$\mathrm{T}$} & \multirow[b]{2}{*}{ Sig. } & \multicolumn{2}{|c|}{$\begin{array}{l}\text { Collinearity } \\
\text { Statistics }\end{array}$} \\
\hline & B & Std. Error & & & & $\begin{array}{l}\text { Toler } \\
\text { ance }\end{array}$ & VIF \\
\hline 1 (Constant) &,- 038 & ,056 & &,- 682 & ,498 & & \\
\hline Ukuran KAP & ,086 & ,024 &, 539 & 3,636 & ,001 &, 532 & 1,880 \\
\hline Auditor Spes Industri &,- 065 & 023, &,- 411 & $-2,762$ & ,007 &, 529 & 1,889 \\
\hline Opini Auditor & ,024 & ,054 & ,048 & ,441 & ,661 & 975 & 1,026 \\
\hline
\end{tabular}

a. Dependent Variable: Manajemen Laba

Sumber : Hasil Output SPSS v. 22 (data diolah)

Berdasarkan hasil uji statistik pada diatas menunjukkan bahwa

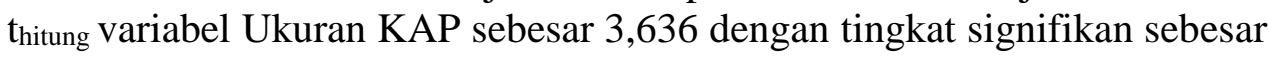
0,001. Dari nilai tabel pada tingkat keyakinan 95\% diperoleh sebesar 1,993 artinya 3,636 lebih besar dari 1,993 karena $t_{\text {hitung }}$ lebih besar dari $t_{\text {tabel }}$ maka H0 ditolak. Secara parsial variabel Ukuran KAP berpengaruh positif signifikan terhadap manajemen laba. Dengan demikian H1 yang menyatakan Ukuran KAP berpengaruh positif terhadap manajemen laba pada perusahaan perbankan yang terdaftar di Bursa Efek Indonesia diterima.

Berdasarkan hasil uji statistik pada tabel diatas menunjukkan bahwa

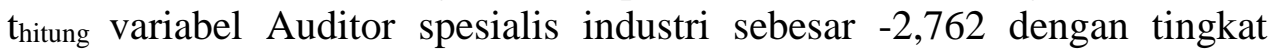
signifikan sebesar 0,007. Dari nilai tabel pada tingkat keyakinan 95\% diperoleh sebesar 1,993 artinya -2,762 lebih kecil dari 1,993 karena thitung lebih kecil dari tabel maka H0 ditolak. Secara parsial variabel Auditor spesialis industri berpengaruh negatif signifikan terhadap manajemen laba. 
Dengan demikian $\mathrm{H} 2$ yang menyetakan Auditor spesialis industri berpengaruh negatif signifikan terhadap manajemen laba pada perusahaan perbankan yang terdaftar di Bursa Efek Indonesia diterima.

Berdasarkan hasil uji statistik pada tabel diatas menunjukkan bahwa

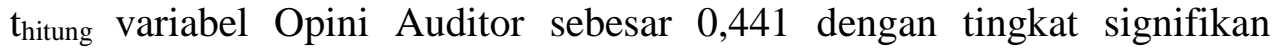
sebesar 0,661. Dari nilai $t_{\text {tabel }}$ pada tingkat keyakinan 95\% diperoleh sebesar 1,993 artinya 0,441 lebih kecil dari 1,993 karena thitung lebih kecil dari tabel maka H0 diterima. Secara parsial variabel Opini Auditor berpengaruh positif tidak signifikan terhadap manajemen laba. Dengan demikian H3 yang menyetakan Opini Auditor berpengaruh negatif terhadap manajemen laba pada perusahaan perbankan yang terdaftar di Bursa Efek Indonesia ditolak.

Tabel 5. Hasil Uji F ANOVA $^{a}$

\begin{tabular}{|ll|r|r|r|r|r|}
\hline Model & & Sum of Squares & \multicolumn{1}{c|}{$\mathrm{df}$} & Mean Square & $\mathrm{F}$ & Sig. \\
\hline 1 & Regression &, 074 & 3 &, 025 & 4,501 &, $006^{\mathrm{b}}$ \\
& Residual &, 396 & 72 &, 005 & & \\
& Total &, 470 & 75 & & & \\
\hline
\end{tabular}

a. Dependent Variable: Manajemen Laba

b. Predictors: (Constant), Opini Auditor, Ukuran KAP, Auditor Spes Industri

Sumber : Hasil Output SPSS v. 22 (data diolah)

Berdasarkan tabel hasil uji $\mathrm{F}$ diatas, nilai $\mathrm{F}_{\text {hitung }} 4,501>2,73$ dan nilai signifikan 0,006 < 0,05 maka H0 ditolak dan Ha diterima. Hal ini berarti bahwa ( Ukuran KAP, Auditor spesialis industri dan Opini auditor) secara simultan berpengaruh positif dan signifikan terhadap Variabel dependen (manajemen laba) pada perusahaan perbankan yang terdaftar di Bursa Efek Indonesia.

\section{Pembahasan}

\section{a. Pengaruh Ukuran KAP Terhadap Manajemen Laba}

Berdasarkan hasil uji statistik pada tabel 4.13 diatas menunjukkan

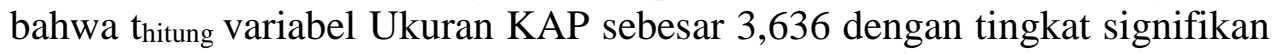
sebesar 0,001. Dari nilai $t_{\text {tabel }}$ pada tingkat keyakinan 95\% diperoleh sebesar 1,993 artinya 3,636 lebih besar dari 1,993 karena thitung lebih besar dari $t_{\text {tabel }}$ maka H0 ditolak. Secara parsial variabel Ukuran KAP berpengaruh positif signifikan terhadap manajemen laba pada perusahaan perbankan yang terdaftar di Bursa efek Indonesia.

Hal ini dikarenakan KAP Big Four dengan keahlian dan reputasi yang dimilikinya terbukti mampu membatasi perilaku manajemen laba 
yang dilakukan manajer dan mampu memberikan jaminan kualitas audit yang lebih baik daripada KAP NonBig Four sehingga penggunaan KAP yang besar dapat mencegah emiten berlaku curang dalam menyajikan suatu laporan keuangan yang tidak relevan ke masyarakat. Karena auditor dari KAP Big Four memiliki kemampuan dan keahlian dalam bidang akuntansi dan auditing sehingga memiliki kemampuan menilai secara objektif dalam mengaudit suatu laporan keuangan sehingga bisa mendeteksi kesalahan penyajian posisi keuangan yang dilakukan oleh manajer perusahaan. penelitian ini didukung oleh Sugiarti (2016) yang menyatakan ukuran KAP berpengaruh signifikan terhadap manajemen laba pada perusahaan perbankan yang terdaftar di bursa Efek Indonesia (BEI).

\section{b. Pengaruh Auditor Spesialis Industri Terhadap Manajemen}

\section{Laba}

Berdasarkan hasil uji statistik pada tabel 4.13 diatas menunjukkan bahwa thitung variabel Auditor spesialis industri sebesar -2,762 dengan tingkat signifikan sebesar 0,007. Dari nilai tabel pada tingkat keyakinan 95\% diperoleh sebesar 1,993 artinya -2,762 lebih kecil dari 1,993 karena $t_{\text {hitung }}$ lebih kecil dari $t_{\text {tabel }}$ maka $\mathrm{HO}$ ditolak. Secara parsial variabel Auditor spesialis industri berpengaruh negatif signifikan terhadap manajemen laba.

Hal ini disebabkan karena perusahaan yang diaudit oleh auditor spesialis industri memiliki manajemen laba yang lebih tinggi dibandingkan dengan perusahaan yang diaudit oleh auditor yang bukan auditor spesialis industri. Sehingga ditemukan bahwa spesialisasi industri auditor berpengaruh negatif terhadap manajemen laba. penelitian ini didukung oleh Christian (2014) dan Rahmadika (2011) yang menyatakan bahwa auditor spesialis industri berpengaruh negatif signifikan terhadap manajemen laba pada perusahaan perbankan yang terdaftar di bursa Efek Indonesia (BEI).

\section{c. Pengaruh Opini Auditor Terhadap Manajemen Laba}

Berdasarkan hasil uji statistik pada tabel 4.13 diatas menunjukkan bahwa thitung variabel Opini Auditor sebesar 0,441 dengan tingkat signifikan sebesar 0,661. Dari nilai $t_{\text {tabel }}$ pada tingkat keyakinan $95 \%$ diperoleh sebesar 1,993 artinya 0,441 lebih kecil dari 1,993 karena $t_{\text {hitung }}$ lebih kecil dari tabel maka H0 diterima. Secara parsial variabel Opini Auditor berpengaruh positif tidak signifikan terhadap manajemen laba. Hal yang memungkinkan tidak berpengaruhnya opini auditor dikarenakan manajemen laba merupakan bentuk aktivitas yang tidak melanggar aturan dan laporan keuangan yang dibuat oleh emiten yang melakukan manajemen laba masih berada pada konteks aturan yang berlaku. 
Hasil sejalan dengan penelitian yang dilakukan oleh Wijayanti dan Triani (2020) yang menyatakan opini auditor tidak berpengaruh dan tidak signifikan terhadap manajemen laba pada perusahaan perbankan yang terdaftar di Bursa Efek Indonesia (BEI).

\section{KESIMPULAN DAN SARAN}

\section{Kesimpulan}

Berdasarkan hasil penelitian dan pembahasan mengenai pengaruh ukuran KAP, Auditor spesialis industri dan opini auditor terhadap manajemen laba pada perusahaan perbankan yang terdaftar di Bursa Efek Indonesia yang dilakukan terhadap 43 sampel perusahaan dengan tahun penelitian 2017-2018. Maka diperoleh kesimpulan sebagai berikut :

1. Kualitas audit yang diproksikan dengan Ukuran KAP (auditor big four dan auditor Non-big four) berpengaruh positif dan signifikan terhadap Manajemen laba.

2. Kualitas audit yang diproksikan dengan Auditor spesialis industri tidak berpengaruh negatif dan signifikan terhadap manajemen laba.

3. Kualitas audit yang diproksikan dengan opini auditor tidak berpengaruh positif dan signifikan terhadap manajemen laba.

4. Berdasarkan hasil perhitungan yang telah dilakukan bahwa secara bersama-sama variabel ukuran KAP, auditor spesialis industri dan opini auditor berpengaruh positif dan signifikan terhadap manajemen laba pada perusahaan perbankan yang terdaftar di Bursa Efek Indonesia.

\section{Saran}

Berdasarkan kesimpulan diatas maka penulis akan memberikan saran sebagai berikut:

1. Penelitian selanjutnya, diharapkan dapat memperluas penelitian dengan mengembangkan jumlah variabel bebas dalam penelitian dan jumlah sampel, tidak hanya perusahaan perbankan tetapi dapat menggunakan perusahaan lain yang sudah go public di Indonesia. Sehingga diperoleh hasil penelitian yang mungkin lebih akurat.

2. Peneliti selanjutnya, diharapkan dapat memperluas tahun atau periode penelitian lebih dari 2 tahun dan menggunakan metode penelian yang berbeda pula untuk mendapatkan hasil yang lebih baik. 


\section{DAFTAR PUSTAKA}

Arens, Alvin,Randal J. Elder dan Mark S. Beasley.2014. Auditing \& Jasa Assurance Pendekatan Terintegrasi. Edisi Kelima belas, JilidI. Jakarta: Erlangga.

Amijaya, Muhammad Dody dan Andri Prastiwi. 2013. Penaruh Kualitas Audit Terhadap Manajemen Laba. Diponegoro Journal Of Acconting, Volume 2, Nomor 3, Tahun 2013

Christiani, Ingrid dan Yeterina Widi Nugrahanti. 2014. Pengaruh kualitas Audit terhadap Managemen Laba. Jurnal Akuntansi dan Keuangan, Vol. 16, No. 1, Mei 2014, 52-62.diakses 4 desember 2019

Ghozali, Imam. 2018. Aplikasi Analisis Multivariate dengan Program SPSS. Semarang: Badan Penerbit Universitas Diponegoro.

Indriani, Yohana. 2010. "Pengaruh Kualitas Auditor, Corporate Governance, Leverage dan Kinerja Keuangan terhadap Manajemen Laba (Studi pada Perusahaan Perbankan yang Terdaftar di Bursa Efek Indonesia (BEI) Tahun 2006-2008)". Semarang : Universitas Diponegoro.

Mulyadi.2002. Auditing. Buku I Edisi Keenam.Jakarta: SalembaEmpat

Ningsaptiti, Restie. 2010. "Analisis Pengaruh Ukuran Perusahaan dan Mekanisme Corporate Governance terhadap Manajemen Laba (Studi Empiris pada Perusahaan Manufaktur yang terdaftar di Bursa Efek Indonesia 2006-2008)". Skripsi Mahasiswa S-1. Semarang : Universitas Diponegoro.

PricewaterhouseCoopers, 2002. "Mandatory Rotation of Audit Firms : Will it mprove Audit Quality?". PricewaterhouseCoopers LLP, New York.

Rachmawati, Yulia. 2013. Pengaruh Kualitas Auditor Terhadap Manajemen Laba ( Studi Empiris Pada Perusahaan Non Keuangan yang Terdaftar di BEI Tahun 2009- 2011

Rahmadika. (2011), "Pengaruh kualitas Auditor terhadap Manajemen Laba (Studi Epiris pada Perusahaan Manufaktur yang terdaftar di Bursa Efek Indonesia Tahun 2008-2009)", Skripsi Universitas Diponegoro. Diakses 4 desember 2019

Rusmin (2010), "Auditor Quality and Earnings Management:Singaporean Evidence", Managerial Auditing Journal, 25(7), 618-638.

Sugiarti, Ika. 2016. Pengaruh Kualitas Audit Terhadap Manajemen Laba ( Studi pada Perusahaan Perbankan di Bursa Efek Indonesia tahun 2012-2014). Muhammadiyah Jember Journal Of Accounting 
Sukrisno, Agoes.2017. Auditing (Petunjuk Praktis Pemeriksaan Akuntas Oleh Akuntan Publik). Edisi kelima, Jilid Satu Jakarta: Salemba Empat.

Scott, William R, 2009. Financial Accounting Theory.FifthEdition. Canada Prentice Hall

Wijayanti, Dina Eka dan N. N. A. Triani. 2020. Pengaruh Leverage, Pertumbuhan Perusahaan, Audit Tanure, dan Opini Audit Terhadap Manajemen Laba (Studi pada Perusahaan Pertambangan yang Terdaftar di Bursa Efek Indonesia 2013-2017). Akunesa:Jurnal Akuntansi Unesa, Vol.8, No.3 